\title{
Circular economy model framework in the European water and wastewater sector
}

\author{
Marzena Smol ${ }^{1,3} \cdot$ Christian Adam $^{2} \cdot$ Michał Preisner $^{3}$
}

Received: 22 August 2019 / Accepted: 10 December 2019 / Published online: 16 January 2020

(c) The Author(s) 2020

\begin{abstract}
One of the key elements in the transformation towards a circular economy (CE) is providing more sustainable practices for resources and waste management. Improvement actions focused on transformation towards a CE should be targeted at all groups of materials and waste. As water is essential for human survival and well-being and plays a significant role in sustainable development (SD), the actions related to the reuse of water and the recovery of raw materials from wastewater and other water-based waste should be taken. The paper presents a proposition for a new CE model framework in the water and wastewater sector, which includes the six following actions: reduction—prevent wastewater generation in the first place by the reduction of water usage and pollution reduction at source; reclamation (removal)—an application of effective technologies for the removal of pollutants from water and wastewater; reuse-reuse of wastewater as an alternative source of water supply (non-potable usage), recycling—recovery of water from wastewater for potable usage; recovery—recovery of resources such as nutrients and energy from water-based waste, and rethink-rethinking how to use resources to create a sustainable economy, which is `free` of waste and emissions. The novelty of the proposed CE model framework is that it presents possible ways of implementing CE principles in the water and wastewater sector, with a strong emphasis not only technological but also organisational and societal changes. Application of the proposed model may help to further transform the European economy to the CE model. Moreover, the indicated model can be significant tool supporting an assessment of local or regional progress towards $\mathrm{CE}$ in the water and wastewater sector and further environmental management and planning.
\end{abstract}

Keywords Circular economy $(\mathrm{CE}) \cdot$ Zero waste $\cdot$ Waste management $\cdot$ Wastewater $\cdot$ European Union (EU)

\section{Introduction}

Transformation towards a circular economy (CE) has become a popular and important issue in environmental management in recent years [1]. The CE concept is a global strategy which was introduced first into China in 2002 [2, $3]$ as the key strategy for the national development plan $[4,5]$. In the European economy [6], the CE concept was

Marzena Smol smol@meeri.pl

1 AGH University of Science and Technology, Antoniego Gramatyka 10 Str., 30-071 Cracow, Poland

2 Department 4 Materials and The Environment, Bundesanstalt für Materialforschung und-prüfung (BAM), Unter den Eichen 87, 12205 Berlin, Germany

3 Polish Academy of Sciences, Mineral and Energy Economy Research Institute, Wybickiego 7a Str., 31-261 Cracow, Poland adopted in 2014 in the first communication concerning the CE 'Towards a circular economy: a zero waste programme for Europe' [7]. The European Commission (EC) defined the $\mathrm{CE}$ as a 'system which keeps the added value in products for as long as possible and eliminates waste'. In 2015, in the second communication 'Closing the loop-An EU action plan for the Circular Economy' [8] an extended definition was provided: ' $\mathrm{CE}$ is a system where the value of products, materials and resources is maintained in the economy for as long as possible, and the generation of waste is minimised'. In the given definitions, two important aspects play a key rolemore rationale use of resources and waste management. It should be noted that the improvement actions should be targeted at all groups of resources and waste, in every branch of industry. In this context, more rationale usage of water resources (which are under pressure) and more sustainable practices of wastewater are expected, as a way towards the $\mathrm{CE}$ in the water and wastewater sector. 
Water and wastewater management is one of the biggest challenges for the CE as many kinds of industries depend on water [9] and a limited access to clean water resources can limit both production capacity and profits. Moreover, a disposal of wastewater, which can cause environmental damage, is an inherent element of water management [10] as more than half of the global freshwater $\left(2212 \mathrm{~km}^{3}\right.$ per year) is released into the environment as wastewater in the form of municipal and industrial effluent and agricultural drainage water. The remaining $44 \%$ of global freshwater $\left(1716 \mathrm{~km}^{3}\right.$ per year) is mainly consumed by agriculture through evaporation in irrigated cropland [11]. To prevent contamination of the environment by insufficiently treated wastewater introduced into natural receivers, the European Union (EU) introduces systematic changes in the structure of water-based waste disposal practices, which are important elements of the water management. On the European level, the EC is working on common principles to coordinate Member States' efforts to improve the protection of European waters in terms of quantity and quality, to promote more sustainable water usage, to protect aquatic ecosystems and terrestrial ecosystems and wetlands directly depending on them, to contribute to the control of transboundary water problems and to safeguard and develop the potential uses of Community waters [12]. The CE assumptions adopted by the EC could strengthen actions recommended in water and wastewater directives to protect water resources and environment in Europe, but this requires a new approach to water and wastewater management, and development and implementation of innovation, however not only in technologies but also in organisation, policies, society and finance structures [8]. In recent decades, water scarcity which is a consequence of increased urbanization or climatic variability has forced people to take action to reduce pressure on water resources mainly through the reduction of water demand. Anyway, this practice alone is not sufficient to maintain the quality of life that high-quality water services are necessary. Therefore, further efforts should be sought that will make it possible to lessen the pressure on water resources, while limiting the occurrence of wastewater, and if it arises-to use the most efficient methods of its treatment to protect the health and life of people, and the environment. Moreover, water and wastewater disposal is a significant part of the path to a CE model due to water being a carrier of materials (e.g. nutrients as phosphorus and nitrogen) and energy. Integrated initiatives should be proposed to intensify the implementation of the CE principles in water and wastewater sector. In many cases, the sustainable management of water resources is not sufficient, because the production, service and domestic activities still generate large amounts of wastewater that must be managed. Therefore, special attention should be paid to the wastewater disposal practices, as it is a part of waste management. In practice, a number of waste prevention methods are available, and they are summarized as the so-called 2Rs: reduction-prevent wastewater generation in the first place by the reduction of water usage and pollution reduction at source and reuse-reuse of wastewater as an alternative source of water supply [13], 3Rs: reduction, reuse and recycling - recovery or reclamation of water from wastewater for potable or non-potable usage [14-17], and 4Rs: reduction, reuse, recycling and recovery-recovery of resources as nutrients and energy from water-based waste $[18,19]$. In the current paper, a circular economy model framework for the water and wastewater sector is proposed, based on the mentioned waste prevention rules: reduction, reuse, recycling and recovery, and also two additional aspects: reclamation (removal)—focused on highly effective removal of pollutants (widely used in water and sewage management), and rethink - which is the basis for introducing systematic changes in the whole value chain. The overall goal of this paper is to develop a model framework covering the possibilities of applying circular economy principles in the water and wastewater sector. The structure of the current work is as follows:

presentation of the main aspects of the CE model in the EU's water and wastewater sector,

methods used in this paper,

clarifying the importance of management of resources and waste in the CE model, clarifying the CE approach in the water and sewage sector,

characteristics of the proposed CE model framework for the water and wastewater sector, conclusions.

\section{Methods and scope}

The current study is divided into two parts. The first part is a summary of the state of knowledge in the research area showing the importance of implementing the $\mathrm{CE}$ approach in the water and wastewater sector. Special attention is paid to the management practices of waste generated in the wastewater sector. There is a wide spectrum of possible actions in a closed cycle, through better management of both water and further raw materials (e.g. phosphorus) which are present in the wastewater environment. In the second part of the research, the circular economy model framework in water and wastewater sector has been developed. It was proposed based on the identification of the role of integration of all possible actions such as a reduction of wastewater generation, wastewater reuse and recycling, removal of hazardous pollutants and recovery of valuable materials from wastewater. The presented CE model framework includes the following elements: reduction, reclamation (removal), reuse, 
recycling, recovery and rethink, an integration of these solutions is proposed as a path towards CE in the water and wastewater sector.

The proposed model is recommended based on a comprehensive review of world literature. The selection of primary literature was based on full-text databases (Elsevier Scopus, Elsevier ScienceDirect, Web of Knowledge, Wiley Online, Google Scholar, EUR-lex, Eurostat) and available publications. The choice of literature was associated with the use of a few keywords: 'waste management', 'water', 'wastewater', 'sewage', 'circular economy', 'CE', 'reuse', 'recycling', 'removal', 'reclamation', 'recovery', which have been selected by the team of four experts-one technological scientist, an economist, a production-line manager, and a representative from an environmental organization. The amount of used reviewed articles reached 63 documents. There are also EU official documents as Communications, EU Directives and regulations (18 documents), international reports (13 documents), and statistic reports (3 documents) used in the review. An important source of data comes from the Waste Framework Directive (Fig. 1), EU statistics report (Fig. 2), the Report (Water and Circular Economy White Paper 2018) of the Ellen MacArthur Foundation (Table 1). The proposed model was developed based on the articles reviewed and the research carried out by the authors of this publication (Fig. 3).

\section{The importance of waste management in the CE model}

Waste management is one of the most significant priorities in the EU [20, 21]. The general framework for waste management is provided by Council Directive 2008/98/
EC on waste (Waste Framework Directive 2008/98/EC) [22], which established the waste hierarchy, set out the basic waste management definitions including defining when a by-product is not waste and end-of-waste status is reached. It forced EU countries to take necessary measures to recover, reuse and recycle waste and created a European recycling society, controlled hazardous waste through a ban on the mixing of hazardous waste with the exception of household waste, and established principles such as extended producer responsibility (EPR) and the 'polluter pays` principle [23]. The EC underlined that the most important objective of the EU waste policy is to minimise the negative effects of the generation and management of waste on human health and the environment. Moreover, the waste policy is also designed to reduce the use of resources, and favour the practical application of the waste hierarchy [24]. The adopted scheme for a waste management hierarchy [22], with an indication of water and wastewater aspects is presented in Fig. 1. It establishes a priority order for prevention, preparation for reuse, recycling and energy recovery through to disposal, such as landfilling $[25,26]$. The main goal of the EU in realising the hierarchy presented is to achieve sustainable development in waste management [27], leading to a reduction of its generation and the safe recovery of waste [22]. It is in line with the CE model and a 'zero waste' strategy [7] which is one of the most visionary concepts for solving waste problems by striving for:

- Zero waste of resources: energy, materials, human,

- Zero emissions: water, air, soil,

- Zero waste in activities: production, administration,

- Zero waste in product life: transportation, use, end of life,

- Zero use of toxic materials: processes and products [28].

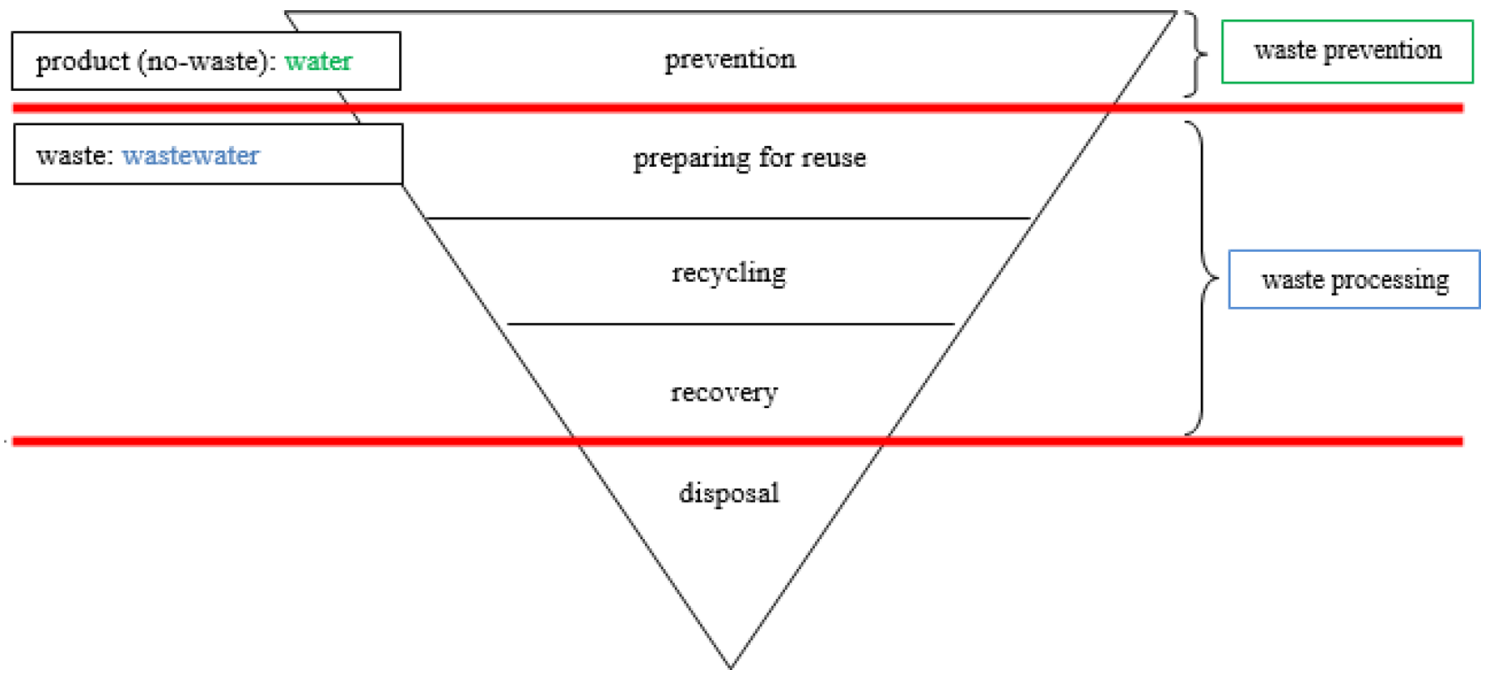

Fig. 1 Water and wastewater aspects in the waste management hierarchy [own diagram based on the Waste Framework Directive 2008/98/EC] 


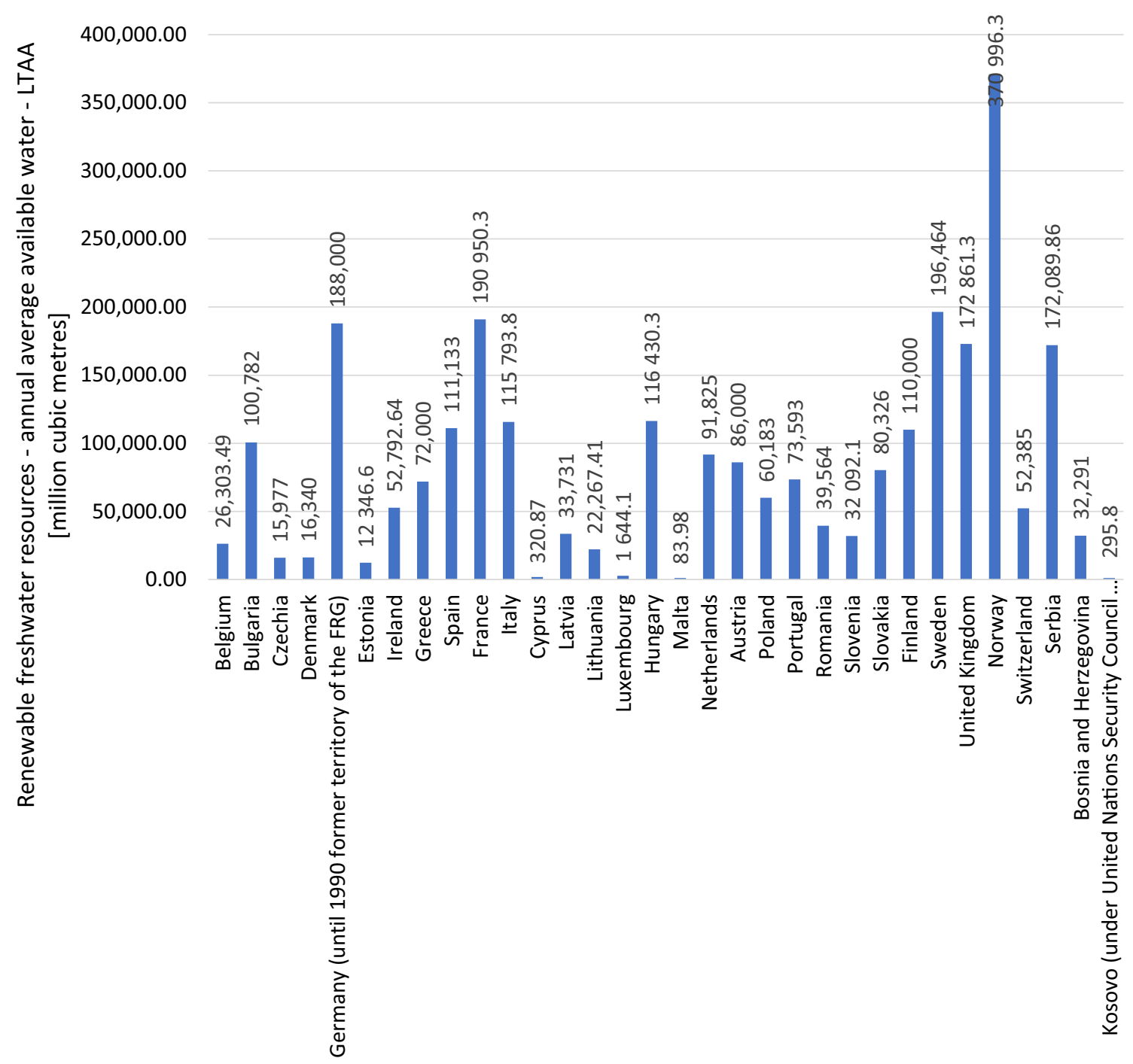

Fig. 2 The renewable freshwater resources in EU countries in 2017 (Eustostat 2018)

Table 1 Relationship between CE principles and water systems management (White Paper, Ellen MacArthur Foundation 2018)

\begin{tabular}{lll}
\hline CE principles & Water systems management \\
\cline { 1 - 2 } $1 \quad$ Name & Designing of waste externalities & $\begin{array}{c}\text { Optimisation of the amount of energy, minerals, and chemicals use in the operation of water systems in } \\
\text { concert with other systems } \\
\text { Optimisation of consumption of water within a sub-basin in relation to adjacent sub-basins (e.g. use in } \\
\text { agriculture or evaporative cooling) } \\
\text { Use of measures or solutions which deliver the same outcome without using water } \\
\text { Optimisation of resource yields (water use and reuse, energy, minerals, and chemicals) within water } \\
\text { systems } \\
\text { Optimisation of energy or resource extraction from the water system and maximise their reuse } \\
\text { Optimisation of value generated in the interfaces of water systems with other systems } \\
\text { Maximisation of environmental flows by reducing consumption and non-consuming use of water } \\
\text { Preservation and enhancing of the natural capital (e.g. river restoration, pollution prevention, quality of } \\
\text { effluent, etc.) } \\
\text { Ensuring minimum disruption to natural water systems from human interactions and use }\end{array}$ \\
&
\end{tabular}



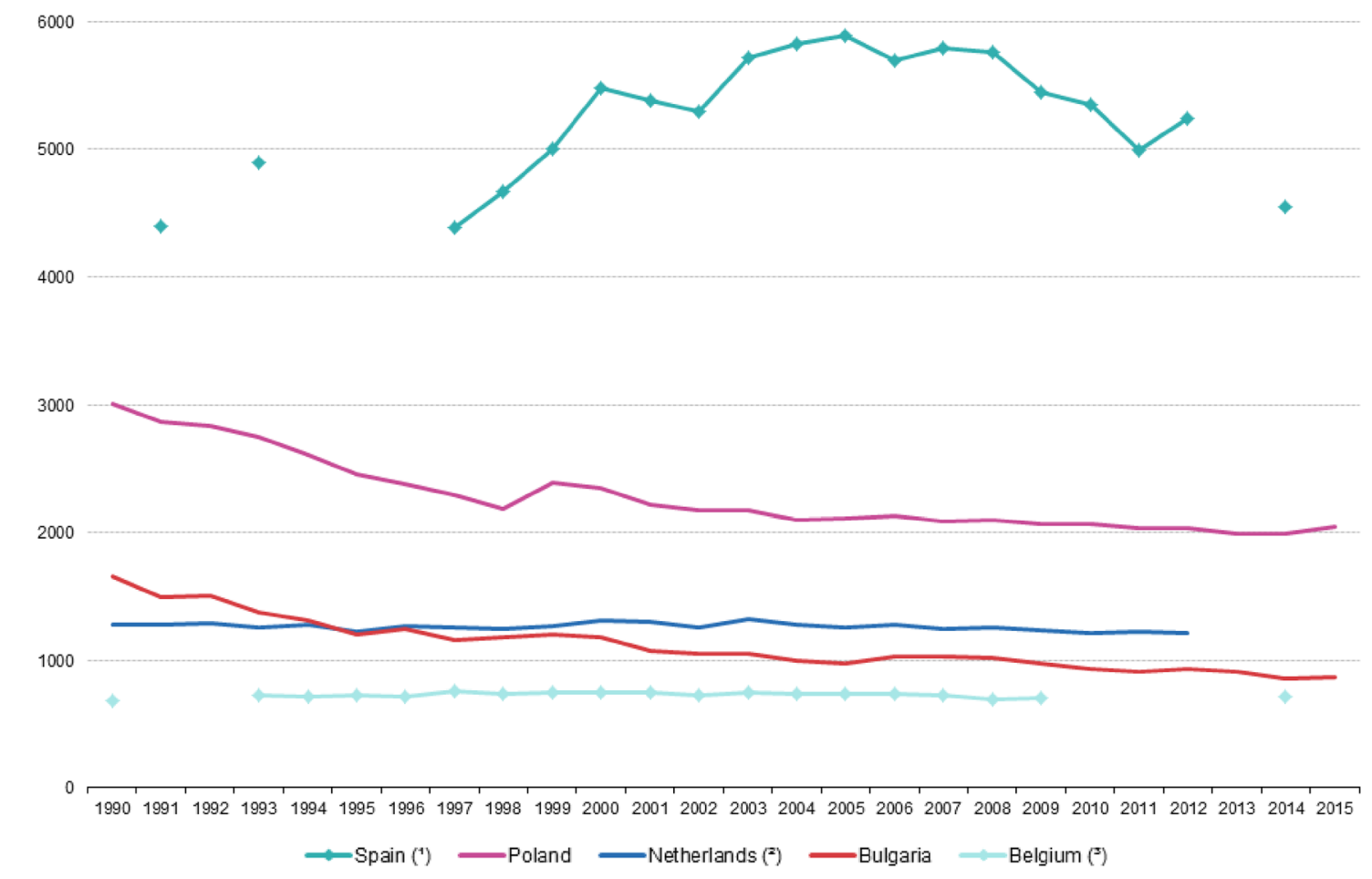

(1) 1990, 1992, 1994-96, 2013 and 2015: not available. (2) 2013-2015: not available.

(3) 1991-92, 2010-13; 2015: not available.

Fig. 3 Total freshwater abstraction by public water supply in the selected EU Member States, 1990-2015 (million $\mathrm{m}^{3}$ ) [41]

It has to be pointed out that even in a highly circular model some elements of linearity will remain due to the fact that virgin resources are required, and residual waste is disposed of [7].

The EC is working on documents, which have set the context for many of the policy instruments to be implemented [29] and could, therefore, be considered the most significant drivers in the changes seen in the waste management sector $[30,31]$. One of the most important documents in relation to the transition to the CE model in the waste sector (next to the Waste Directive) is the CE Package [8], which establishes a concrete and ambitious programme of action for the whole cycle (production, consumption, waste management, marketing of secondary raw materials) and a revised legislative proposal on waste, which sets clear targets for the reduction of waste and establishes a credible long-term path for waste management and recycling. In the CE Action Plan, the EC declared to revise provisions to promote greater use of economic instruments, develop and improve the general requirements for EPR schemes, simplify and harmonise the definitions and calculation methods, and step up its work with all Member States to improve waste management on the ground, including avoiding overcapacity in residual waste treatment. Moreover, the EC also declared to assist
EU countries and regions in ensuring that Cohesion Policy investments in the waste sector contribute to supporting the targets of EU waste legislation and are guided by the European waste hierarchy [8].

In 2018, the EC proposed the monitoring framework for measuring the transformation towards the $\mathrm{CE}$ in European countries [32]. Since the economy is a very wide-ranging concept (e.g. it applies to all branches of industry) there is no indicator that can be a single measurement for the CE. However, several existing indicators could be helpful in measuring performance in selected areas that directly or indirectly contribute to the development of a CE [33]. The EC proposed to group those indicators into the four following categories:

1. production and consumption,

2. waste management,

3. secondary raw materials,

4. competitiveness and innovation.

The data regarding the $\mathrm{CE}$ indicators were adopted in the official European statistics and are available in the Eurostat databases. In the waste management group two indicators were proposed: 
1. overall recycling rates-the recycling rate of municipal waste and all waste apart from major mineral waste,

2. the recycling rates for specific waste streams - the recycling rate for overall packaging waste, plastic packaging, wood packaging, waste electrical and electronic equipment, recycled biowaste per capita and the recovery rate of construction and demolition waste [32].

The first results of the adopted CE Action Plan in the waste sector indicate that waste management generally shows positive developments (inter alia EU recycling rates for municipal waste increased from $37 \%$ in 2008 to $46 \%$ in 2016), yet with significant room for improvement and differences between Member States and across waste streams. These indicators will be regularly monitored by the Commission in the years to identify key trends and patterns by monitoring [32]. This is the key element in understanding how the various elements of the $\mathrm{CE}$ are developing over time to help to identify the success factors in the individual EU countries and to assess whether sufficient action has been taken. The results of monitoring the waste management systems should form the basis for setting new priorities towards the long-term objective of a CE in the waste sector [34].

\section{Circular economy approach in the water and wastewater sector}

Water is essential for human survival and well-being and plays a significant role in sustainable development and circular economy [35]. It is a renewable resource since the amount on Earth always remains the same as water continuously works its way through the water cycle. Water is a key element not only in the life of the planet's inhabitants, but it plays a very important role in many sectors of the economy, as agriculture, production, heating and cooling, tourism and other service sectors. As it is an extremely valuable source, it must be used in a sustainable way. However, as a consequence of human activity and economic development, water resources are under pressure [36]. Therefore, the protection of water resources has become an important topic of many environmental debates and is indicated in numerous documents and strategies for development at the regional, national, European and even global levels. Many aspects of water issues were incorporated in the Sustainable Development Goals (SDGs) adopted in 2015 [37], as SGD2-zero hunger (end hunger, achieve food security and improved nutrition and promote sustainable agriculture), SDG6-clean water and sanitation (ensure availability and sustainable management of water and sanitation for all), SGD7-affordable and clean energy (ensure access to affordable, reliable, sustainable and modern energy for all), SGD 14-life below water (conserve and sustainably use the oceans, seas and marine resources for sustainable development), and other. The inclusion of water issues in SDGs was made possible thanks to the long-term hard work of various stakeholders involved in the implementation of sustainable development principles as policy makers, non-governmental organisations (NGOs), individual companies, academia and research centres, and society [38].

On the European level, water management has changed over the past 30 years. The EU Member States have made significant progress in improving water quality in European freshwater reservoirs, adopting EU legislation, in particular, the Water Framework Directive [12], the Urban Waste Water Treatment Directive [39] and the Drinking Water Directive [40]. These key legal acts form the basis of the EU's commitment to improving water status in Europe. One of the achievements is the significant improvement of water quality in the European freshwater and coastal bathing in the last four decades. In 2017, over 21,500 bathing areas were inspected across the $13 \mathrm{EU}$ countries, $85 \%$ of them met the most stringent standards confirming the excellent state of water. Thanks to the provisions laid down in EU legislation concerning the quality of bathing and wastewater, EU Member States have managed to solve the problem of bathing water pollution through the discharge of wastewater or water from agricultural land, which posed a threat to human health and aquatic ecosystems. However, despite the progress made, the overall state of many European water bodies is still uncertain. Currently, renewable freshwater resources in the EU (calculated as the sum of internal flow and external inflow) are equal to 2,112,679.2 million $\mathrm{m}^{3}$ per year and they differ between the Member States. The freshwater availability in a given country depends on climate conditions and transboundary water flows (external flows). As can be seen from Fig. 2, the greatest quantities of freshwater resources (annual average available water-LTAA) are noted in the developed countries such as Sweden, Germany, France and United Kingdom (UK), while in the European Free Trade Association (EFTA) and candidate countries higher longterm averages were recorded for Norway. On the European level, there is also interesting phenomena related to the development of freshwater abstraction by public water supply. It is shown in Fig. 3 that for selected EU Member States that between 1990 and 2015 there was a marked decrease in water abstraction in countries that joined the EU in 2004 or 2007 (e.g. Bulgaria, Poland). This fact is affected by various factors in different countries, as:

- reduction of water losses by improved maintenance of the networks,

- implementation of water-saving household equipment,

- increasing level of awareness about the importance of water and its cost and the environmental consequences of wasting this valuable resource. 
Anyway, the abstraction rates were relatively stable in countries as Belgium and the Netherlands, which are the majority of the remaining Member States [41].

According to the latest European Environmental Agency (EEA) Water Europe report [42] the vast majority of lakes, rivers, river estuaries and coastal waters in Europe have problems with achieving the EU target of a minimum of good ecological status of the EU set in the EU framework water directive. The objective of EU policy is to significantly reduce the negative effects of pollution, excessive water abstraction and other factors exerting pressure on water and to ensure a sufficient amount of good water quality for both people and the environment. The improvement actions focused also on the management of wastewater. In recent years, wastewater treatment and the reduction of the use of nitrogen $(\mathrm{N})$ and phosphorus $(\mathrm{P})$ in agriculture have led in particular to a significant improvement in water quality.

It should be pointed that the EC seeks to harmonize the situation at European level so that there are no such differences in individual countries and even regions. For example, in Poland, in the financial perspective for 2014-2020 (in which applications are still being submitted) there are a number of possibilities for financing investments in the water and sewage sector. In addition, an increased support was allocated to less developed regions, such as eastern Poland (mainly rural communities), which should make it possible to adapt the situation in this region in the field of water and wastewater management to other, more developed regions of the country, and other European countries.

The EC emphasis the importance of sustainable management of water and wastewater as one of the elements in the transition towards the circular economy. The first EC communication on the $\mathrm{CE}$ is strongly connected with waste management as it focuses on the 'zero waste' strategy. The main circular approaches in waste management have been proposed. In this document, it was indicated that the sustainable resource management includes interactions within waste, water, energy and raw materials. In this context, integration of activities in terms of both water-as a resource and waste - as a source of raw materials and energy should be developed and implemented. In general, improvement actions in the water management should be proposed, but also - in the management of water-based waste to recover raw materials and energy occurring in it. The EC also pointed out that waste generated in the water and wastewater sector as wastewater, sewage sludge or sewage sludge ash is an important source of biogenic raw materials [7]. One of the most important biogenic raw material is phosphorus [43], which is a limited source [44]. For the European economy, it is indicated as a critical raw material (CRM) due to its high economic and strategic importance associated with a high supply risk [45]. Europe has very limited primary resources of $\mathrm{P}$ [46] and is dependent on outside providers
( $88 \%$ for phosphate rock and $100 \%$ for phosphorus) [45]. Therefore, the EC considers developing a policy framework on phosphorus to enhance its recycling, foster innovation, improve market conditions and mainstream its sustainable use in EU legislation on fertilizer, food, water and waste. Moreover, the EC indicated other specific waste challenges for the water and wastewater sector, e.g. full implementation of the measures in the revised EU waste legislation package ( $13 \%$ by 2020 and $27 \%$ by 2030) could positively affect marine waters quality. Setting a dedicated reduction target for 2020 would give a clear signal to European countries currently developing measures to achieve 'good environmental status' for marine waters by the 2020 deadline under the Marine Strategy Framework Directive [47], and would provide an impetus for the development of marine litter action plans within the four Regional Sea Conventions. The EC indicated some key aspects of water and wastewater management from the point of view of zero waste strategy. Anyway, no more recommendations have been proposed in first European CE communication [7].

In the second CE communication (2015), the EC proposed 54 actions, including initiatives related to the water and wastewater sector. Due to water scarcity has worsened in some parts of the EU in previous decades, with damaging effects on the European environment and economy, boosting the market for secondary raw materials and water reuse is proposed. Next to the water-efficiency measures, the reuse of treated wastewater in safe and cost-effective conditions is recommended. It is a valuable however under-used means of increasing water supply and alleviating pressure on overexploited water resources in Europe. The importance of water reuse in agriculture was underlined due to it contributes to nutrients recycling by substitution of solid fertilizers. Therefore, the EC proposed many actions to promote the reuse of treated wastewater, including legislation on minimum requirements for reused water. The following waterrelated proposals have been presented in this communication, in the area of the market for secondary raw materials:

- 2017: proposed legislation setting minimum requirements for reused water for irrigation and groundwater recharge,

- 2016-2017: promotion of safe and cost-effective water reuse, including guidance on the integration of water reuse in water planning and management, inclusion of best practices in relevant Best available techniques Reference document (BREFs), and support to innovation (through the European Innovation Partnership and Horizon 2020) and investments [8].

Both initiatives have been included in the European Commission's Work Programmes from 2017. They should contribute to the political priorities set by the EC to promote a 
more circular economy. Other key legislative proposals on fertilizers are also pointed. In this case, the recycled nutrients are indicated, with strong emphasis on the phosphorus recovery from water-based waste. In 2016, the 'Proposal laying down rules on the making available on the market of CE marked fertilizing products' has been published [48], and in 2019 the "'Regulation laying down rules on the making available on the market of EU fertilizing products" has been adopted [49]. Fertilizers produced from waste [50] meeting quality, safety and labelling requirements and limits of organic, microbiological and physical contaminants will be able to be traded freely within the EU and receive the CE marking [49].

In the previous mentioned communication on monitoring framework for measuring the transformation towards the CE in the EU, which has been published in January 2018, the $\mathrm{CE}$ indicators have been proposed only for selected groups of waste. Among these groups, no aspects were considered that are related to the measurement of circularity in the water and wastewater sector, which is one of the most important considerations for health and social life. In future, the list of CE indicators should be extended to issues related to the reuse of water and the recovery of raw materials and energy from wastewater, sewage sludge and sewage sludge ash and other water-based waste [32].

In May 2018, the EC presented new rules to stimulate and facilitate water reuse in the EU for agricultural irrigation. The general objective is to "contribute to alleviating water scarcity across the EU, in the context of adaptation to climate change, notably by increasing the uptake of water reuse, in particular for agricultural irrigation wherever this is relevant and cost-effective while ensuring the maintenance of a high level of public health and environmental protection'. In general, reuse of treated wastewater shows lower environmental impact than for example water transfers or desalination. Moreover, it offers a range of economic, environmental and social benefits, and it extends the water life cycle, thereby helping to preserve water resources, which is in full compliance with the CE objectives. The proposed Regulation in combination with other non-regulatory actions as outlined in the CE Action Plan is a proportionate response to the specific objective of fostering the development of safe reuse of treated wastewater. The treated wastewater could be used for a wide variety of purposes, by many industries e.g. in agriculture. In 2015, agricultural irrigation was mentioned as the main potential source of demand for reused water due to the high potential in terms of its higher uptake, scarcity alleviation and European relevance [51].

In the report on the implementation of the CE Action Plan, which has been published in March 2019, the EC underlined that water management is an important part of the transformation towards CE [34]. The proposed in 2015 circular actions seek to boost the market for reused water, to tackle water scarcity across Europe. Therefore, in 2018, the dedicated legislation setting minimum requirements for reused water for agricultural irrigation was proposed [51]. It should be also pointed that practices on water reuse are integrated into water planning and management [52] or in the review of the relevant Best Available Techniques Reference Documents (BREFs) [34].

Summarizing all presented information, it can be stated that water plays a critical role in the world's transition from the linear consumption of resources towards their circular use. Water issues are incorporated into the CE model due to water being a carrier of materials and energy. Therefore, it is important to develop and implement technologies focused on water reuse or recovery of resources and energy in water and sewage management in accordance with the 'nutrientsenergy-water' paradigm ('NEW').

Moreover, the relationship between CE principles and water systems management needs to be identified and disseminated among individuals, organisations and companies to integrate their efforts in this area. The water-circular economy relationship was presented in the White Paper developed by the Ellen MacArthur Foundation in 2018 [53]. This foundation is one of the most important actor in the transition process to the $\mathrm{CE}$ in Europe. It published a lot of reports and documents on CE presenting the main CE approaches, CE models and White Papers dedicated to specific sectors or areas. The most important assumptions of the Water and Circular Economy White Paper are presented in Table 1. They include:

- design of waste externalities, with the strong focus on optimization of water and energy, minerals, and chemicals usage,

- keeping the resources in use, with focus on the optimization of resource yields and energy or resource extraction from the water system,

- regeneration of natural capital by the reduction of consumption and non-consuming use of water.

The White Paper focuses on the presentation of main CE principles and their connections to the sustainable water management, including key intersection topics as indication of water as a carrier of chemicals, particles and droplets (dissolved and suspended state) which could be treated as a potential resource or pollutant. As it was mentioned before, water is a carrier of biogenic raw materials [53]. Therefore, there is high potential for recovery of nitrogen $[54,55]$ and phosphorus [56-58] from wastewater and produce the fertilizers $[59,60]$. The White Paper also underlines the importance of water in the economic systems, including enterprises, created value and its impact. An application of CE assumptions in water and wastewater sector can bring new business models development, improvement of functional 
performance and impact, and greater value and commercial opportunity [53].

Currently, the issues of transformation water and wastewater sector to the CE model are also one of the key works of the International Water Association (IWA). In 2016, the IWA proposed the framework that may support the water utility leaders in the identification of opportunities that can boost their progress along the pathway to the CE. The following approaches have been identified:

- integrated urban resource management, connecting to stakeholders beyond traditional boundaries (urban and basin),

- leadership innovation,

- new business models.

The general idea assumes that water cycle needs to be managed from catchment to consumer, back to catchment, and the transition to the CE model needs to consider both the consumption and production of resources across this entire value chain. It also must create both connections and synergies within the water cycle for more efficient water management and connections outside the sector [61]. Such an integrated approach takes into account not only water management but also a water-based waste as sewage, sewage sludge, sewage sludge ash and other. It should be also noted that water-based waste management (via reuse or recycling) may face numerous barriers such as public perception to pricing and technological, regulatory and safety challenges [36]. However, more sustainable management of all the above water-based resources is necessary for the achievement of the environmental, social and economic objectives indicated in the CE Action Plan [8].

\section{Circular economy model framework in the water and sewage sector}

To transform the European economy to the CE model it is necessary to provide more sustainable practices of resources and waste management [32]. This also applies to the water and wastewater sector, and its basic elements-water, wastewater, sewage sludge, sewage sludge ash and other residues. As it was mentioned, in practice, some prevention methods are already used in waste management, as.

- 2Rs: reduction and reuse,

- 3Rs: reduction, reuse and recycling,

- 4Rs: reduction, reuse, recycling and recovery.

As far as the implementation of the CE principles in the water and wastewater sector is concerned, an extension of the existing xRs techniques cited above is proposed. The proposed CE model framework includes two additional aspects:

- reclamation (removal) - focused on highly effective removal of pollutants (characteristic for a water and wastewater sector), and

- rethink-which is the basis for introducing systematic changes in the whole value chain for water (key element of the transformation toward $\mathrm{CE}$ in all branches of the economy).

All the above elements must be in the line not only with the $\mathrm{CE}$ assumptions but also with the waste management hierarchy. Therefore, in the proposed model, CE actions are ordered from the most desirable solution to the least recommended. The exception is rethink, which is applied to all other elements of the model. The concept of CE model framework in the water and wastewater sector is presented in Fig. 3.

\section{Reduce}

Reduce is the first option in the presented concept and the best way to save the quality of the environment. It indicates that the first element in preventing wastewater generation should involve considering the reduction of water usage and pollution reduction at source through better planning and design. Currently, human activities use over half of all accessible water runoff. Approx. $90 \%$ of total water use is for industrial purposes and less than $10 \%$ is for domestic purposes. Households are the smallest consumers of water, however, they have a large potential impact as they can experiment with strategies to develop water-saving habits which can be implemented outside of the home. Household water use is the largest growing sector (by upwards of $80 \%$ over the next 25 years) and it is a testing ground for developing the strategies and social behavior needed to reduce water use in agriculture and industry. There are several benefits arising from the reduction of water consumption, such as a decrease in individual expenses and time spent acquiring water, a decrease in demand for the extension of water supply systems and facilities as well as for costly wastewater treatment plant (WWTP) facilities, and the improvement of the availability of water for other uses and purposes [62]. It should be pointed out that the environmental attitudes and environmental behavior of people at home should be transferred to workplaces. However, the deep literature review shows that attitude change is not necessarily a pre-requisite for behavior change in the workplace [63, 64]. This requires further raising people's awareness of the importance of making changes in every aspect of life, both in households and in the workplace. The society is becoming more and more environmentally aware and it could be assumed that they 
will try to adopt some changes in their households and workplaces in the nearest future, as a consequence of 'zero waste' initiatives and fashion [27]. The behavior transfer creates a great opportunity to introduce the methods to reduce water consumption in companies, which is particularly important in the industrial plants that depend on water consumption (Fig. 4).

\section{Reclamation (removal)}

Reclamation is associated with highly effective techniques for the removal of pollutants $[65,66]$ from wastewater and it is the second option in the presented hierarchy. Wastewater is treated due to the necessity for sanitation in the maximum possible number of cities, towns and villages [67], and the consequent need for safe disposal of the wastewater collected into the environment after treatment [68], complying at the same time with the disposal regulations $[69,70]$. According to the EU regulations and national laws, treatment of wastewater is obligatory $[39,40]$ due to the discharge of untreated effluent in water bodies leading to eutrophication, human health risks and Greenhouse Gas (GHG) emissions in the form of nitrous oxide and methane. Moreover, treated wastewater should be reused whenever appropriate [71]. To reuse the treated wastewater, it is necessary to decompose or remove dangerous substances and impurities [72] such as microbial pathogens, particulates, nutrients [73], toxic organic compounds $[74,75]$ and other matter. There are several treatment options which differ from each other due to the different types of wastewater (industrial, municipal) which require various treatment methods [76]. Biological, physical, chemical and a combination of those methods are applied in WWTPs to meet specific water quality objectives [77]. Currently, unit wastewater treatment operations and processes are combined together to provide primary, secondary and tertiary treatment [78]. In the European WWTPs, $3.1 \%$ of the load is treated at primary level, $28.5 \%$ at secondary level and $68.4 \%$ at tertiary level [79]. Primary treatment is related to the initial treatment processes (physical and chemical), secondary treatment deals with the biological treatment of wastewater, and in tertiary treatment processes, wastewater (treated by in the primary and secondary processes) is converted into good quality water that can be used for different types of purpose-potable (drinking) and non-potable (industrial). In the tertiary process, almost $100 \%$ of the contaminations are removed and the water is converted into the safe quality for a specific use [78]. Treated wastewater provides an alternative source of water, which is extremely important in areas where water is scarce. Moreover, from irrigation to industrial purposes to potable supply,

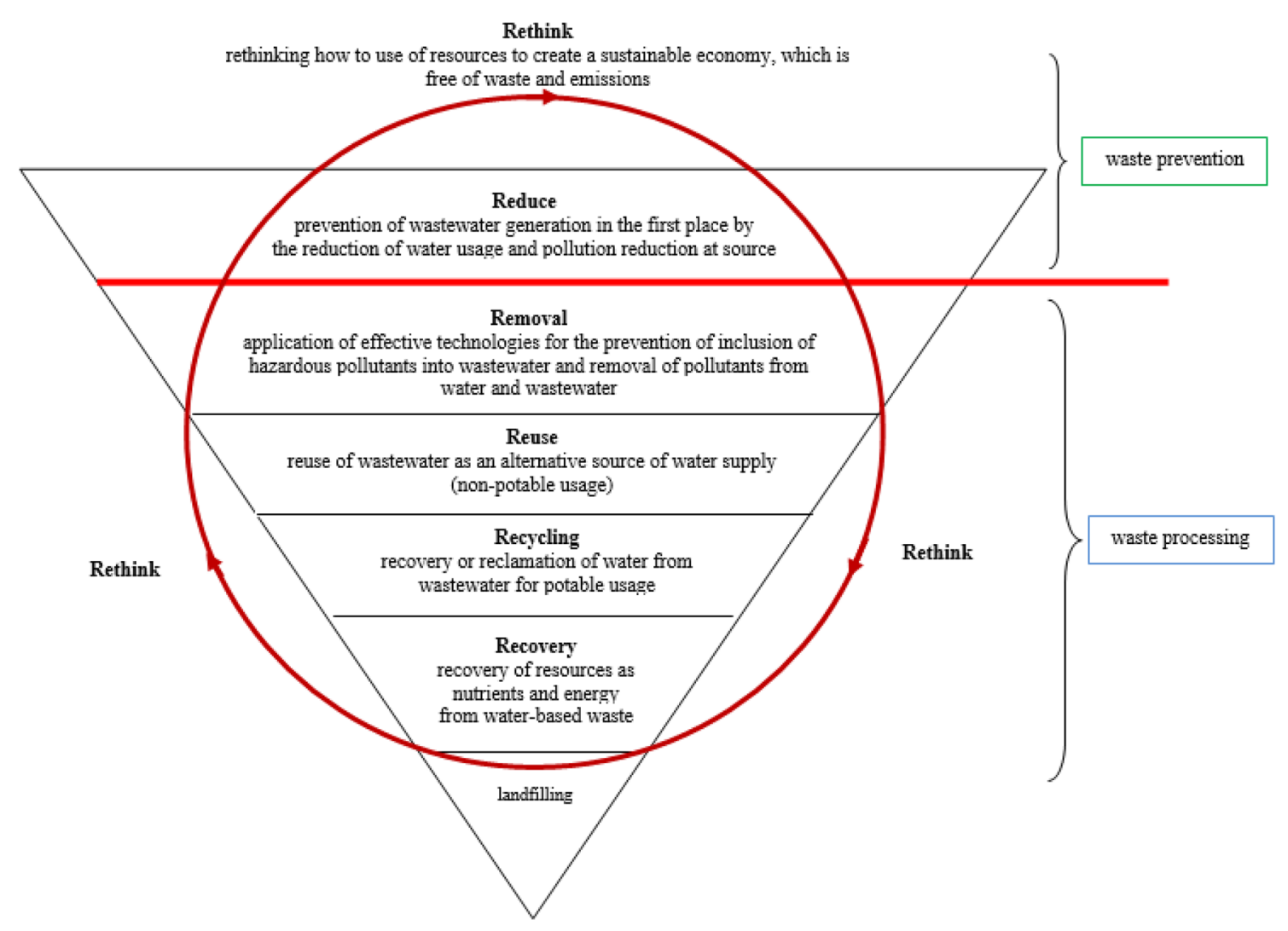

Fig. 4 The CE model framework in the water and wastewater sector 
wastewater treated to the required quality could replenish water supplies and reduce the availability/demand gap [36].

\section{Reuse}

Reuse is the third option in the proposed model framework. Water can be non-potable reused as an alternative fresh water supply, in particular for agricultural irrigation, urban landscape irrigation and other urban uses, and industrial practices [80]. Reuse of treated wastewater as an alternative source of water supply has been well recognised and embedded within international, EU and national strategies [36]. The United Nations (UN) Sustainable Development Goal on Water (SDG 6) specifically targets a substantial increase in safe reuse globally by 2030 [37]. Moreover, water reuse is a priority area in the Strategic Implementation Plan of the European Innovation Partnership on Water, and maximisation of water reuse is a specific objective in the Communication 'Blueprint to safeguard Europe's water resources' [81]. It has been indicated that reuse of treated wastewater could bring important environmental, economic and social benefits [82]. By water reuse, it is possible to quantitatively improve the status of the environment (alleviating pressure by substituting for abstraction) and qualitatively (relieving the pressure of discharges from urban WWTPs to sensitive areas) [83]. Compared to alternative sources of water such as desalination or water transfer, in many cases water reuse requires lower investment costs and energy. Treated wastewater can also be reused in agriculture, in particular providing a reliable continuity of water supply during the irrigation period. It can reduce the risk of crop failure and income loss. Another important aspect is the use of treated wastewater with a controlled level of nutrients which can also reduce the use of additional fertilizers, thus bringing further benefits in the form of savings for farmers and the environment and reducing the need for wastewater treatment. According to information provided by the $\mathrm{EC}$, water reuse contributes to the broader water sector, which has been indicated as a key component of the European eco-industrial landscape. The global water market has been growing rapidly in recent years, and it is estimated that it will reach 1 trillion Euros by 2020 . Taking into account the above forecast, water reuse provides a significant potential in terms of the creation of new green jobs in water-related industry (it is estimated that a $1 \%$ rise in the rate of growth of the water industry in the EU could create up to 20 thousand new jobs) [84]. An example of water recuse in the wastewater sector is the use of water (grey water) that enters the drains from showers and sinks in houses for irrigation purposes. The rest of the water (so-called 'black water') can be applied for irrigation after going through a conventional primary or secondary wastewater treatment process (e.g. filtration or disinfection). Wastewater treated in this way is $100 \%$ recycled and can be used to irrigate golf courses, cemeteries, parks, and other landscaping. Another example of water recycling is the use of rainwater that is collected or harvested from stormwater drainage systems. In urban areas, this includes rainwater runoff from buildings, roads and open land, which is usually evacuated by drains [85].

\section{Recycling}

Recycling is the fourth option in the proposed CE model. Water recycling is related to the recovery or reclamation of water from wastewater for potable (drinking) usage, which can be supplied back to the water system either directly or indirectly [85]. Although recycling does help to conserve resources and reduce waste, it should be noted that there are high economic and environmental costs associated with wastewater collection and recycling [86]. Therefore, recycling should only be considered for wastewater which cannot be reduced or reused [87]. In the water recycling, high effective technologies for the removal of pollutants from wastewater must be applied, as for example membrane techniques-nanofiltration (NF), reverse osmosis (RO), or forward osmosis (FO). Membrane technology has been used for the water recycling from palm oil mill effluent (POME). This technique shows high potential for eliminating the environmental problem, and in addition, this alternative treatment system offers water recycling. The treated effluent is characterized by high quality and crystal-clear water that can be used as the source of drinking water production or the boiler feed water [88].

\section{Recovery}

The recovery of materials is the fifth option in the proposed model. Wastewater has considerable potential to support circular approaches due to the wealth of potentially recoverable resources in wastewater-including inorganic nutrients such as nitrogen and phosphorus, organic fertilizers, biogas, biopolymers, heat, cellulose, heavy metals, pharmaceutical products, and water. The aspect of the recovery of nutrients is indicated in the first implementing regulation of the CE Action Plan - a proposal laying down rules on the making available of $\mathrm{CE}$ marked fertilizer products on the market [48]. One of the most important elements which can be recovered in the wastewater sector is phosphorus. P-recovery potential appears in several places in WWTPs, such as wastewater outflow from the treatment plant, sedimentary liquid (leachate), dehydrated sewage sludge and sewage sludge ash [89]. In each of the subsequent processes of wastewater treatment and sewage sludge processing, a smaller volume of the substrate used for the recycling of $\mathrm{P}$ is obtained, however, the concentration of $\mathrm{P}$ per unit volume increases and reaches up to $64 \mathrm{~g} \mathrm{P} / \mathrm{kg}$ dry matter (d.m.). One 
of the most promising methods is the recovery of $\mathrm{P}$ in the form of struvite from the liquid phase of wastewater. Struvite precipitation can bring several benefits-it can improve the operation of treatment processes and helps to reduce the environmental impacts of effluent discharge on receiving water bodies. Moreover, it can secure a renewable supply of $\mathrm{P}$ which is a critical raw material for the European economy due to there being no significant $\mathrm{P}$ mines existing in the EU [90]. Phosphorus is imported from outside providers, some of which are considered politically risky, such as Morocco and Russia. Due to one of the main fertilizer constituents being phosphate rock and taking account of Europe's need to import more than $90 \%$ of its requirements, domestic P-rich waste could potentially cover about $20-30 \%$ of the EU's demand for phosphate fertilizers. The EU has indicated that there is currently a largely unexploited investment potential remaining in relation to this. A rise in recycling rates and a decrease in import dependency for $\mathrm{P}$ are considered essential to European agriculture and are mentioned as one of the key objectives in coming years, following the revision of the EU Fertilizer Regulation, to extend its scope to nutrients from secondary sources and organic sources [91]. Other possibility of recovery of nutrients from sewage sludge is composting of it. It could be used, for example, in urban agriculture and organic farming, but also in gardens, landscaping or horticulture. Anyway, it should be mentioned that the composition of the sewage sludge could be complicated due to this waste stream is rich in micro- and macroelements, but also it could contain toxic compounds and pathogenic organisms. Therefore, the sewage sludge treatment methods should be adopted in specific WWTPs. Moreover, the amount of sewage sludge that can be used as fertilizers is subject to limits provided in the European and national regulations [48, 49].

\section{Rethink}

Rethink is the last option in the adopted CE model, but the most important from the perspective of transformation process towards $\mathrm{CE}$, which requires the holistic changes in all value chain of water and wastewater, i.e. in all previously mentioned $\mathrm{xR}$ rules. Therefore, rethink should be applied to all previously described elements of the CE model framework. The whole concept of the $\mathrm{CE}$ is about rethinking how to use resources to create a sustainable economy, which is free from waste and emissions. It requires systematic change from the current linear model of 'take, make, waste' to the CE model economy where the 'reduce, reuse, recycle, recover $\rightarrow$ rethink' process is put into practice. In the 'zero waste programme' the EC defined the waste targets for a move to a recycling society. A recycling-oriented society should be built based on the transfer of knowledge and solutions (technological, organisational, societal and financial) from more advanced regions in the realisation of $\mathrm{CE}$ targets [7]. Currently, Europe has made substantial progress in turning waste into a resource and promoting sustainable ways of waste management such as recycling. However, performance varies considerably between European countries and regions. Some of them have already effectively imposed legal restrictions and installed technologies for nutrient recovery in WWTPs (as in Switzerland and Germany) [92]. In others, no research is conducted in this area. Due to the transition to the CE model in Europe, public awareness is one of the major driving forces [93] and more and more attention is paid to actions focused on change in society's way of thinking. Therefore, new educational and promotional activities are conducted to increase the level of public knowledge of the importance of water protection [94]. It should bring a change in behavior of all consumers as a significant factor in the passage from a linear to a circular economy. Transformation towards the CE in the water and sewage sector should take into account an integrated approach to water management by increasing the scope and division of responsibilities incumbent on administrations and integration with other fields, including energy, transport, navigation, agriculture, forestry, fishing, nature protection in the broad sense, tourism, social communication, spatial planning, as well as regional policy.

The novelty of the presented circular economy model framework is that it presents possible ways of implementing CE principles in the water and wastewater sector, including the importance not only technological but also organisational and societal changes. Its application may help the European economy further transform into the CE model. It is extremely important for water-addicted companies and wastewater operators, due to their ecologically aware decisions regarding the implementation of sustainable and circular solutions in water and wastewater sector can speed up the process of transformation toward CE. It should be clearly underlined that the circular economy is now an irreversible global trend on a large scale. The European Commission strongly indicates that efforts need to be intensified at national, EU and global levels to fully close the loop and take advantage of the competitive advantage that the circular economy provides for EU businesses.

All mentioned water protection, conservation, reuse and recycling methods, next to materials recovery solutions produce substantial environmental benefits, arising from reductions in water diversions, and reductions in the impacts of wastewater discharges on environmental water quality [95]. These directions of waste and wastewater management are in line with both CE concept and the strategic direction for EU environmental policy outlined by the 7th Environmental Action Programme (EAP, adopted in 2013) and in the targets defined in the Europe 2020 Strategy which plans to turn the EU into a smart, sustainable and inclusive economy delivering high levels of employment, productivity and social 
cohesion [96]. In setting the vision for 2050, it refers to "the $\mathrm{CE}$ where nothing is wasted and where natural resources are managed sustainably' [23]. The transition to the $\mathrm{CE}$ will also help to meet the objectives of the 2030 Agenda for Sustainable Development due to it encourages a more efficient use of water and water-based waster. In this context, the CE perspective may bring water and wastewater innovation [97] that supports the implementation of the proposed CE model framework for the water and wastewater sector. Moreover, the indicated model can be a significant tool supporting an assessment of local or regional progress towards CE in the water and wastewater sector and further environmental management and planning.

\section{Conclusions}

Management of water and wastewater is an important part of the CE model due to many industries depends on water and it is a carrier of materials and energy. The EC underlines the importance of water and wastewater disposal practices in the $\mathrm{CE}$ documents, which indicates that the CE objectives can be achieved in water and wastewater sector through:

- more sustainable management of water resources,

- more rational disposal and processing of wastewater and other water-based waste.

In some cases, the sustainable management of water resources is not enough to reach $\mathrm{CE}$ objectives due to the production, service and domestic activities still generate large amounts of wastewater that must be disposed. Therefore, special attention is paid to wastewater disposal, which is an integral part of waste management. In this paper, the circular economy model framework for water-based waste management is proposed. It includes six following actions (ways) helpful in the implementation of CE principles in the water and wastewater sector:

- Reduction-prevent wastewater generation in the first place by the reduction of water usage and pollution reduction at source,

- Reclamation (removal) application of effective technologies for the removal of pollutants from water and sewage,

- Reuse-reuse of treated wastewater as an alternative source of water supply for non-potable usage,

- Recycling-recovery of water from wastewater for potable usage,

- Recovery-recovery of resources as nutrients and energy from water-based waste,

- Rethink-rethinking how to use resources to create a sustainable economy which is free of waste and emissions.
The novelty of the presented CE model framework concerns the integration of all possible ways of implementation of CE principles in the water and wastewater sector, including technological, organisational and societal changes. Application of the proposed model may help the European economy to make further transformations towards the $\mathrm{CE}$ model.

Acknowledgements This work was funded by the project "Monitoring of water and sewage management in the context of the implementation of the circular economy assumptions", that is financed by the Polish National Agency for Academic Exchange (NAWA) within the International Academic Partnerships Programme (No. PPI/ APM/2019/1/00015/U/00001/ZU/00002).

Open Access This article is licensed under a Creative Commons Attribution 4.0 International License, which permits use, sharing, adaptation, distribution and reproduction in any medium or format, as long as you give appropriate credit to the original author(s) and the source, provide a link to the Creative Commons licence, and indicate if changes were made. The images or other third party material in this article are included in the article's Creative Commons licence, unless indicated otherwise in a credit line to the material. If material is not included in the article's Creative Commons licence and your intended use is not permitted by statutory regulation or exceeds the permitted use, you will need to obtain permission directly from the copyright holder. To view a copy of this licence, visit http://creativecommons.org/licenses/by/4.0/.

\section{References}

1. Ferronato N, Rada EC, Portillo MAG, Cioca LI, Ragazzi M, Torretta V (2019) Introduction of the circular economy within developing regions: a comparative analysis of advantages and opportunities for waste valorization. J Environ Manag 230:366-378

2. Geng Y, Zhu Q, Doberstein B, Fujita T (2009) Implementing China's circular economy concept at the regional level: a review of progress in Dalian China. Waste Manage 29(2):996-1002

3. Guttman D, Young O, Jing Y, Bramble B, Bu M, Chen C et al (2018) Environmental governance in China: interactions between the state and "nonstate actors". J Environ Manag 220:126-135

4. Zhu Q, Geng Y, Lai KH (2010) Circular economy practices among Chinese manufacturers varying in environmental-oriented supply chain cooperation and the performance implications. J Environ Manag 91(6):1324-1331

5. Li J, Song X, Guo Y, Yang Q, Feng K (2019) The determinants of China's national and regional energy-related mercury emission changes. J Environ Manag 246:505-513

6. Imbert E, Ladu L, Tani A, Morone P (2019) The transition towards a bio-based economy: a comparative study based on social network analysis. J Environ Manag 230:255-265

7. Commission of European Communities (2014) Communication No. 398, 2014. Towards a circular economy: a zero waste programme for Europe (COM no. 398, 2014)

8. Commission of European Communities (2015) Communication No. 614, 2015. Closing the loop-an EU action plan for the circular economy (COM no. 614, 2015)

9. Mauchauffee S, Denieul MP, Coste M (2012) Industrial wastewater re-use: closure of water cycle in the main water consuming industries - the example of paper mills. Environ Technol 33(19):2257-2262 
10. Kowalewski Z, Neverova-Dziopak E, Preisner M (2018) An attempt at development of a regression model for estimating BOD5 values of municipal wastewater. Ochrona Srodowiska 40(1):21-27

11. The United Nations World Water Development Report (2017). https://unesdoc.unesco.org/images/0024/002475/247553e.pdf. (UNWWDR, 2017). Accessed 22 Aug 2019

12. Directive 2000/60/EC of the European Parliament and of the Council of 23 October 2000 establishing a framework for community action in the field of water policy (EU Water Framework Directive-WFD) (2000/60/EC)

13. Sakai SI, Yano J, Hirai Y, Asari M, Yanagawa R, Matsuda T, Yoshida H, Yamada T, Kajiwara N, Suzuki G, Kunisue T, Takahashi S, Tomoda K, Wuttke J, Mählitz P, Rotter VS, Grosso M, Fruergaard Astrup T, Cleary J, Oh GJ, Liu L, Li J, Ma H, Chi NK, Moore S (2017) Waste prevention for sustainable resource and waste management. J Mater Cycles Waste Manag 19(4):1295-1313

14. Moriguchi Y (2007) Material flow indicators to measure progress toward a sound material-cycle society. J Mater Cycles Waste Manag 9(2):112-120

15. Sakai SI, Yoshida H, Hirai Y, Asari M, Takigami H, Takahashi S, Tomoda K, Peeler MV, Wejchert J, Schmid-Unterseh T, Ravazzi Douvan A, Hathaway R, Hylander LD, Fischer C, JongOh G, Chi NK (2011) International comparative study of $3 \mathrm{R}$ and waste management policy developments. J Mater Cycles Waste Manag 13(2):86-102

16. Liu L, Liang Y, Song Q, Li J (2017) A review of waste prevention through $3 \mathrm{R}$ under the concept of circular economy in China. J Mater Cycles Waste Manag 19(4):1314-1323

17. Usapein $P$, Chavalparit $O$ (2015) Evaluating the performance of $3 R$ options to reduce landfill wastes using the $3 R$ indicator (3RI): case study of polyethylene factories in Thailand. J Mater Cycles Waste Manag 17(2):303-311

18. Oduro-Kwarteng S, Anarfi KP, Essandoh HMK (2016) Source separation and recycling potential of municipal solid waste in Ghana. Manag Environ Qual Int J 27(2):210-226

19. Hammed TB, Wandiga SO, Mulugetta Y, Sridhar MKC (2018) Improving knowledge and practices of mitigating green house gas emission through waste recycling in a community, Ibadan, Nigeria. Waste Manag 81:22-32

20. Gaska K, Generowicz A (2017) Advanced computational methods in component-oriented modelling of municipal solid waste incineration processes. Arch Civ Eng Environ 10(1):117-130

21. Makara A, Kowalski Z (2018) Selection of pig manure management strategies: case study of Polish farms. J Clean Prod 172:187-195

22. Council Directive 2008/98/EC on waste (Waste Framework Directive 2008/98/EC) (2008/98/EC)

23. Towards a circular economy-waste management in the EU, STUDY European Parliamentary Research Service, Scientific Foresight Unit (STOA), 2017 (STOA 2017)

24. Fischer C (2011) The development and achievements of EU waste policy. J Mater Cycles Waste Manag 13(1):2-9

25. Pires A, Martinho G (2019) Waste hierarchy index for circular economy in waste management. Waste Manag 95:298-305

26. Mihai FC (2018) Waste collection in rural communities: challenges under EU regulations. A case study of Neamt County, Romania. J Mater Cycles Waste Manag 20(2):1337-1347

27. Silva A, Rosano M, Stocker L, Gorissen L (2017) From waste to sustainable materials management: three case studies of the transition journey. Waste Manag 61:547-557

28. Curran T, Williams ID (2012) A zero waste vision for industrial networks in Europe. J Hazard Mater 207:3-7
29. Kral U, Morf LS, Vyzinkarova D, Brunner PH (2018) Cycles and sinks: two key elements of a circular economy. J Mater Cycles Waste Manag 21(1):1-9

30. Kulczycka J, Kowalski Z, Smol M, Wirth H (2016) Evaluation of the recovery of Rare Earth Elements (REE) from phosphogypsum waste-case study of the WIZOW chemical plant (Poland). J Clean Prod 113:345-354

31. Generowicz A, Kulczycka J, Kowalski Z, Banach M (2011) Assessment of waste management technology using BATNEEC options, technology quality method and multi-criteria analysis. J Environ Manag 92(4):1314-1320

32. Commission of European Communities (2018) Communication No. 29, 2018. Monitoring framework for the circular economy (COM no. 29, 2018)

33. Eco-Innovation at the heart of European policies (2018) https:// ec.europa.eu/environment/ecoap/indicators/circular-economyindicators_en. Accessed 22 Aug 2019

34. Report from the Commission to the European Parliament, the Council, the European Economic and Social Committee and the Committee of the Regions on the implementation of the Circular Economy Action Plan (COM no. 190, 2019)

35. Decision No. 1386/2013/EU of the European Parliament and of the Council of 20 November 2013 on a General Union Environment Action Programme to 2020 'Living well, within the limits of our planet' (L 354/171)

36. Voulvoulis N (2018) Water reuse from a circular economy perspective and potential risks from an unregulated approach. Curr Opin Environ Sci Health 2:32-45

37. Assembly UG (2015) Transforming our world: the 2030 Agenda for sustainable development. New York: United Nations 2015 (UN 2015)

38. Resolution adopted by the General Assembly on 25 September, Transforming our world: the 2030 Agenda for Sustainable Development (A/70/L.1)

39. Council Directive 91/271/EEC concerning urban waste-water treatment (91/271/EEC)

40. Council Directive 98/83/EC of 3 November 1998 on the quality of water intended for human consumption (Drinking Water Directive) $(98 / 83 / \mathrm{EC})$

41. Water statistics, Eurostat (2018). https://ec.europa.eu/eurostat/stati stics-explained/index.php/Water_statistics (Water statistics 2018). Accessed 22 Aug 2019

42. European waters, Assessment of status and pressures (2018) European Environmental Agency, Luxembourg: Publications Office of the European Union, 2018 (European waters 2018).

43. Krüger O, Adam C (2015) Recovery potential of German sewage sludge ash. Waste Manag 45:400-406

44. Commission of European Communities (2013) Consultative Communication on the Sustainable Use of Phosphorus (COM no. 517, 2013)

45. Commission of European Communities (2017) Communication on the 2017 list of Critical Raw Materials for the EU (COM no. 490, 2017)

46. Smol M, Kulczycka J, Kowalski Z (2016) Sewage sludge ash (SSA) from large and small incineration plants as a potential source of phosphorus-Polish case study. J Environ Manag 184:617-628

47. Directive 2008/56/EC of the European Parliament and of the Council of 17 June 2008 establishing a framework for community action in the field of marine environmental policy (Marine Strategy Framework Directive) (2008/56/EC)

48. Commission of European Communities. Communication on the Circular Economy Package. Proposal for a Regulation of the European Parliament and of the Council laying down rules on the making available on the market of CE marked fertilizing 
products and amending Regulations (EC) No 1069/2009 and (EC) No $1107 / 2009$ (COM no. 157, 2016)

49. Regulation (EU) 2019/1009 of the European Parliament and of the Council of 5 June 2019 laying down rules on the making available on the market of EU fertilising products and amending regulations (EC) No 1069/2009 and (EC) No 1107/2009 and repealing Regulation (EC) No 2003/2003 (2019/1009)

50. Stoklosa H, Kowalski Z, Makara A (2019) Application of circular economy model and cleaner technologies on the example of the Polish agro-food company Farmutil. Przem Chem 98(5):709-714

51. Proposal for a Regulation of the European Parliament and of the Council on minimum requirements for water reuse (COM no. 337, 2018)

52. Common Implementation Strategy for the Water Framework Directive and the Floods Directive, Guidelines on Integrating Water Reuse into Water Planning and Management in the context of the WFD, https://ec.europa.eu/environment/water/pdf/Guide lines_on_water_reuse.pdf, 2016 (Guidelines on Integrating Water Reuse, 2016). Accessed 22 Aug 2019

53. Water and Circular Economy White Paper, Ellen MacArthur Foundation 2018 (White Paper Ellen MacArthur Foundation 2018)

54. Wang Z, Gong H, Zhang Y, Liang P, Wang K (2017) Nitrogen recovery from low-strength wastewater by combined membrane capacitive deionization (MCDI) and ion exchange (IE) process. Chem Eng J 316:1-6

55. Sancho I, Licon E, Valderrama C, de Arespacochaga N, LópezPalau S, Cortina JL (2017) Recovery of ammonia from domestic wastewater effluents as liquid fertilizers by integration of natural zeolites and hollow fibre membrane contactors. Sci Total Environ 584:244-251

56. Amann A, Zoboli O, Krampe J, Rechberger H, Zessner M, Egle L (2018) Environmental impacts of phosphorus recovery from municipal wastewater. Resour Conserv Recycl 130:127-139

57. Smol M, Henclik A, Kulczycka J, Tarko B, Gorazda K, Wzorek Z (2015) Sewage sludge ash (SSA) as a phosphate fertilizer in the aspect of legal regulations. In: Wastes: solutions, treatments and opportunities - selected papers from the 3rd edition of the international conference on wastes: solutions, treatments and opportunities, pp 323-328

58. Gorazda K, Kowalski Z, Wzorek Z (2012) From sewage sludge ash to calcium phosphate fertilizers. Pol J Chem Technol 14(3):54-58

59. Makara A, Kowalski Z (2015) Pig manure treatment and purification by filtration. J Environ Manag 161:317-324

60. Gorazda K, Tarko B, Wzorek Z, Kominko H, Nowak AK, Kulczycka J, Henclik A, Smol M (2017) Fertilisers production from ashes after sewage sludge combustion-a strategy towards sustainable development. Environ Res 154:171-180

61. International Water Association (IWA) (2016). https://iwanetwork.org/ (IWA 2016). Accessed 22 Aug 2019

62. Reduce Water Consumption at Home. https://sswm.info/water -nutrient-cycle/water-use/hardwares/optimisation-water-usehome/reduce-water-consumption-at-home, 2019 (Reduce Water Consumption at Home, 2019). Accessed 22 Aug 2019

63. Wells VK, Taheri B, Gregory-Smith D, Manika D (2016) The role of generativity and attitudes on employees home and workplace water and energy saving behaviours. Tour Manag 56:63-74

64. Young W, Davis M, McNeill IM, Malhotra B, Russell S, Unsworth K, Clegg CW (2015) Changing behaviour: successful environmental programmes in the workplace. Bus Strategy Environ 24(8):689-703

65. Kowalewski Z, Neverova-Dziopak E, Preisner M (2016) Computer simulation of activated sludge process to obtain the minimum eutrophication potential of municipal wastewater. Ochrona Srodowiska 38(3):23-28

66. Dos Santos HS, Ferrarini SF, Flores FQ, Pires MJ, Azevedo CM, Coudert L, Blais JF (2018) Removal of toxic elements from wastewater generated in the decontamination of CCA-treated Eucalyptus sp and Pinus canadense wood. J Mater Cycles Waste Manag 20(2):1299-1309

67. Neverova-Dziopak E, Preisner M (2015) Analysis of methods for determination of conditions of municipal wastewater discharge into recipients in selected countries. Ochrona Srodowiska 37(1):3-9

68. Kudlek E, Dudziak M (2018) The assessment of changes in the membrane surface during the filtration of wastewater treatment plant effluent. Desalin Water Treat 128:298-305

69. Nowak R, Wiśniowska E, Włodarczyk-Makuła M (2018) Effectiveness of degradation and removal of non-steroidal pharmaceuticals which are the most frequently identified in surface water. Desalin Water Treat 134:211-223

70. Salgot M, Folch M, Unit SS (2018) Wastewater treatment and water reuse. Curr Opin Environ Sci Health 2:64-74

71. Konieczny K, Kwiecińska A, Gworek B (2011) The recovery of water from slurry produced in high density livestock farming with the use of membrane processes. Sep Purif Technol 80(3):490-498

72. Bodzek M, Dudziak M (2006) Elimination of steroidal sex hormones by conventional water treatment and membrane processes. Desalination 198(1-3):24-32

73. Tchorzewska-Cieslak B, Wlodarczyk-Makula M, Rak J (2017) Safety analysis of the wastewater treatment process in the field of organic pollutants including PAHs. Desalin Water Treat $72: 146-155$

74. Macherzyński B, Włodarczyk-Makuła M, Wojewódka D (2018) Control of PAHs degradation process under reducing conditions. Desalin Water Treat 117:290-300

75. Wlodarczyk-Makula M, Macherzynski B (2017) The stimulation of degradation of 3-ring of PAHs in sewage sludge during fermentation process. Rocznik Ochrona Srodowiska 19:451-464

76. Sadecka Z, Myszograj S, Sieciechowicz A, Płuciennik-Koropczuk E, Włodarczyk-Makuła M (2016) Impact of selected insecticides on the anaerobic stabilization of municipal sewage sludge. Desalin Water Treat 57(3):1213-1222

77. Smol M, Włodarczyk-Makuła M (2017) The effectiveness in the removal of PAHs from aqueous solutions in physical and chemical processes: a review. Polycycl Aromat Compd 37(4):292-313

78. Gupta VK, Ali I, Saleh TA, Nayak A, Agarwal S (2012) Chemical treatment technologies for waste-water recycling - an overview. RSC Adv 2(16):6380-6388

79. Europe's water in figures. An overview of the European drinking water and waste water sectors. The European Federation of National Water Services 2017, www.danva.dk/media/3645/ eureau_water_in_figures.pdf (Europe's water in figures 2017). Accessed 22 Aug 2019

80. Non-Potable Water Reuse Development, Technologies and International Framework for Agricultural, Urban and Industrial Uses, The German Association for Water, Wastewater and Waste (DWA), 2019 (Non-Potable Water Reuse, 2019)

81. Commission of European Communities (2012) Communication No. 673, 2012. A Blueprint to Safeguard Europe's Water Resources (COM no. 673, 2012)

82. Mostafa MK, Peters RW (2017) Reuse paint wastewater in the manufacture of cement bricks and tiles. J Mater Cycles Waste Manag 19(2):840-850

83. Marszałek M, Kowalski Z, Makara A (2016) Application of pressure-driven membrane techniques for the recovery of water and fertilising components from pig slurry. Czasopismo Techniczne 1(4):77-90 
84. Water reuse, European Commission (2018) ec.europa.eu/environment/water/reuse.htm (Water Reuse, EC 2019)

85. Water Recycling, www.awa.asn.au/AWA_MBRR/Publicatio ns/Fact_Sheets/Water_Recycling_Fact_Sheet/AWA_MBRR/ Publications/Fact_Sheets/Water_Recycling_Fact_Sheet .aspx?hkey=54c6e74b-0985-4d34-8422-fc3f7523aa1d (Water Recycling, AWA 2019). Accessed 22 Aug 2019

86. Kizinievič O, Kizinievič V, Boris R, Girskas G, Malaiškienė J (2018) Eco-efficient recycling of drinking water treatment sludge and glass waste: development of ceramic bricks. J Mater Cycles Waste Manag 20(2):1228-1238

87. The 4Rs - reduction, reuse, recycling and recovery, https://www. iisd.org/business/tools/bt_4r.aspx (4Rs, IISD, 2019). Accessed 22 Aug 2019

88. Ahmad AL, Ismail S, Bhatia S (2003) Water recycling from palm oil mill effluent (POME) using membrane technology. Desalination 157(1-3):87-95

89. Krüger O, Fattah KP, Adam C (2016) Phosphorus recovery from the wastewater stream-necessity and possibilities. Desalin Water Treat 57(33):15619-15627

90. Herzel H, Krüger O, Hermann L, Adam C (2016) Sewage sludge ash-a promising secondary phosphorus source for fertilizer production. Sci Total Environ 542:1136-1143

91. Smol M (2019) The importance of sustainable phosphorus management in the circular economy (CE) model: the Polish case study. J Mater Cycles Waste Manag 21(2):227-238
92. Hukari S, Hermann L, Nättorp A (2016) From wastewater to fertilisers-technical overview and critical review of European legislation governing phosphorus recycling. Sci Total Environ 542:1127-1135

93. Smol M, Avdiushchenko A, Kulczycka J, Nowaczek A (2018) Public awareness of circular economy in southern Poland: case of the Malopolska region. J Clean Prod 197(1):1035-1045

94. Smith HM, Brouwer S, Jeffrey P, Frijns J (2018) Public responses to water reuse-understanding the evidence. J Environ Manag 207:43-50

95. Anderson J (2003) The environmental benefits of water recycling and reuse. Water Sci Technol Water Supply 3(4):1-10

96. Commission of European Communities (2014) Communication No. 130, 2014. Taking stock of the Europe 2020 strategy for smart, sustainable and inclusive growth (COM no. 130, 2014)

97. Casiano Flores C, Bressers H, Gutierrez C, de Boer C (2018) Towards circular economy-a wastewater treatment perspective, the Presa Guadalupe case. Manag Res Rev 41(5):554-571

Publisher's Note Springer Nature remains neutral with regard to jurisdictional claims in published maps and institutional affiliations. 